\title{
A comparative study on efficacy and safety of intravenous iron sucrose and oral iron among anaemic pregnant females
}

\author{
Naheed Zia Khan ${ }^{1 *}$, Mufazzal Ahmad ${ }^{2}$, Akhilesh Dutt Dwivedi', Mukesh Shukla ${ }^{3}$
}

\author{
${ }^{1}$ Department of Obstetrics and Gynecology, Hind Institute of Medical Sciences, Safedabad, Barabanki, Uttar Pradesh \\ India \\ ${ }^{2}$ Senior Consultant Nephrologist, Sahara Hospital, Lucknow, Uttar Pradesh, India \\ ${ }^{3}$ Department of Community Medicine, Hind Institute of Medical, Safedabad, Barabanki, Uttar Pradesh, India
}

Received: 27 July 2017

Accepted: 22 August 2017

\section{*Correspondence:}

Dr. Naheed Zia Khan,

E-mail: naheedziakhan@gmail.com

Copyright: ( ) the author(s), publisher and licensee Medip Academy. This is an open-access article distributed under the terms of the Creative Commons Attribution Non-Commercial License, which permits unrestricted non-commercial use, distribution, and reproduction in any medium, provided the original work is properly cited.

\begin{abstract}
Background: Iron deficiency anaemia (IDA) is the most common medical problem in pregnancy. Both parenteral and oral iron therapies are modalities used for management of anaemia in pregnant females. The present study aimed to compare the efficacy of oral and intravenous iron therapy in improving iron deficiency anaemia in pregnancy and restoring iron stores, compare the pregnancy outcome in the two groups and evaluate their safety.

Methods: This prospective randomized clinical trial conducted among pregnant women between 14 and 36 weeks with established IDA who were treated with IVIS (Intravenous Iron Sucrose) or OI (ferrous sulphate). All patients were monitored for laboratory response and adverse effects. Independent sample-t test, Chi square test and ANOVA were used for statistical analysis. $\mathrm{P}<0.05$ was considered significant.

Results: From first follow up till the end of the study the mean hemoglobin level of IV Group was found to be significantly higher as compared to that of oral Group. The MCV (mean corpuscular volume) values increased to a significant level in the intravenous group as compare to oral. After therapy increase transferrin saturation in the intravenous group were significantly higher at all-time interval than the oral group. The mean neonatal hemoglobin at birth was significantly higher in IV group $16.88 \pm 1.96 \mathrm{gm} / \mathrm{dl}$ than oral group $16.88 \pm 1.96(\mathrm{p}=\mathrm{p}<0.0001)$.

Conclusions: Intravenous iron sucrose is comparatively more efficient in improving haemoglobin than oral iron and has better pregnancy outcomes.
\end{abstract}

Keywords: Anaemia, Intravenous iron sucrose, Oral Ferrous Sulphate

\section{INTRODUCTION}

In India about $52 \%$ of the women of reproductive age group and $74 \%$ of children are anemic. ${ }^{1}$ Iron Deficiency anemia (IDA) is the most common form of nutritional deficiency in the world and approximately $80 \%$ of all anaemia in pregnancy occur due to Iron deficiency.

IDA is the eighth leading cause of disease disability and death in girls and women in the developing world. ${ }^{2} \mathrm{~A}$ rough estimate indicates that an additional $1000 \mathrm{mg}$ of iron is required in pregnancy. ${ }^{3}$ Prevalence of IDA is increased 2-fold or more for those women who are minorities, below the poverty line or with less than 12 years of education. ${ }^{4}$ Risk is also increased with parity, nearly threefold higher for women with 2-3 children and 4-fold greater for women with 4 or more children. ${ }^{5}$

During pregnancy there is significant increase in the amount of iron required to allow for growth of fetalplacental unit and blood loss during pregnancy. ${ }^{6}$ During pregnancy anemia increases four fold from $1^{\text {st }}$ trimester to 
the $3^{\text {rd }}$ trimester in the low income group women monitored by the nutritional surveillance by the CDC. ${ }^{7}$ IDA is associated with poor pregnancy outcome in the form of preterm birth, fetal wastage during pregnancy and increased perinatal mortality and morbidity. ${ }^{8}$ In the mother due to increased incidence of infection, inability to tolerate hemorrhage during labor, cardiac failure and deterioration in the quality of 1 ife. ${ }^{4}$ In these situations, laboratory testing takes on an even greater significance in the assessment of maternal iron deficiency anemia. ${ }^{9}$ Anaemia leads to increased risk of blood transfusion during the peri-partum and postpartum period. ${ }^{9}$

Adequate supplementation of iron either orally or parentally is an important intervention for the management and prophylaxis of iron deficiency states in pregnant women. ${ }^{10}$ However, long experience with oral iron has shown only limited success as a public health strategy. To combat the above problems for particular patient alternative strategies in the form of parental iron therapy has been studied in various parts of worlds and many studies have shown that parental iron is able to replenish iron store more efficiently, completely and faster than oral iron therapy. ${ }^{11}$ Nowadays iron sucrose is being used most commonly in place of iron dextran for intravenous infusion purposes for the correction and prophylaxis of iron deficiency anemia. ${ }^{10,12}$

Various studies here concluded that in IDA effective treatment option is replacement of iron either orally or intravenous. It is now used as second options; if oral iron fails to increase hemoglobin within three weeks; and as first option in profound iron deficiency anemia $(<9 \mathrm{gm} \%)$ in any trimester beyond $>14$ weeks of gestation. Till date there is no good randomized control trial, comparing the efficacy and safety of intravenous versus oral iron therapy for the treatment of IDA in pregnant women in India. We therefore propose to compare the safety and efficacy of intravenous versus oral iron for the treatment of IDA in pregnant women.

\section{METHODS}

It was a double blind randomized control trial. The study was conducted in department of Obstetrics and Gynecology, Vivekananda Polyclinic and Institute of Medical Sciences, Lucknow, Uttar Pradesh.

\section{Sample size}

We proposed to study of a continuous response variable from independent control and experimental subjects with one control per experimental subject.

In a previous study the response within each subject group was normally distributed with standard deviation in the range of $2 \mathrm{mg} / \mathrm{dl}$. If the true difference in the experimental and control means is around $1 \mathrm{mg} / \mathrm{dl}$, we will need to study 80 experimental subjects and 80 control subjects to be able to reject the null hypothesis that the population means of the experimental and control groups are equal with probability (power) 0.8 . The Type I error probability associated with this test of this null hypothesis is 0.05 . The sample size calculated for the study is therefore at least 80 for each group.

\section{Study participants}

A total 220 pregnant females between 16-34 weeks of gestation were primarily enrolled in the present study, out of which 36 patients refused to give consent and 24 were excluded as per criteria. Therefore, the randomization was finally done for 160 patients using block randomization and finally 80 patients were put on oral iron therapy (Group A) as well as intravenous iron sucrose therapy (Group B)

\section{Inclusion criteria}

Includes those patients with serum ferritin less than $20 \mathrm{ng} / \mathrm{ml}$, serum iron less than $60 \mu \mathrm{gm} / \mathrm{dl}$, Total Iron Binding Capacity (TIBC) range 250-435 $\mu \mathrm{g} / \mathrm{dl}$, Transferrin saturation less than 20\%, GBP - Microcytic hypochromic and MCV less than 78fl, MCH less than 28 $\mathrm{pg} / \mathrm{ml}$.

\section{Exclusion criteria}

Excludes those patients with multiple pregnancy, heart disorder with pregnancy, patient with history of antepartum hemorrhage, severe anemia (less than $5 \mathrm{gm}$ /dl) with pregnancy, history of allergy to iron or iron containing medications or any other allergic condition, history of blood transfusion within the prior 120 days and any chronic systemic disorder (inflammatory bowel disease- ulcerative colitis, Crohn's disease, liver and renal disease, hyper-splenism, infection)

\section{Study protocol}

Participants of the study were informed about the nature of the study and then informed consent was taken. Detailed history including age, parity, social economics status, education level, obstetrical history, history regarding any chronic illness like diabetes, tuberculosis, hypertension, thyroid disease, renal and heart disease etc. other causes of anemia i.e. thalassemia etc. were excluded.

Baseline anthropometric data like weight, height, BMI were measured and all data were recorded in a predesigned proforma. Thereafter every subject underwent complete general examination, systemic examination, per-abdomen and per-vaginal examination (if indicated).

Baseline investigation of each subjects were done in the department of pathology of the hospital. Baseline iron profile of each subject was done on registration. $10 \mathrm{ml}$ of venous blood was withdrawn from each subject and was 
dispatched within half an hour to one hour to the department of pathology for estimation of complete blood counts, serum ferritin, serum iron, serum TIBC etc.

\section{Intervention methods}

Initially each subject was dewormified with tablet albendazole (400 mg)

\section{Group A (Oral)}

Received oral treatment of Iron Sulphate (Ferrous sulphate) $300 \mathrm{mg} /$ day (Ferrsolate) one hour before meal. This treatment is also supplemented with $500 \mu \mathrm{g}$ of folic acid per day.

\section{Group B (Intravenous)}

Received Intra Venous Iron Sucrose complex (ISC). ISC was administered as $200 \mathrm{mg}$ of the elemental iron in 100 $\mathrm{ml}$ of $0.9 \%$ of normal saline over one hour every alternate day up to the total calculated dose after a test dose of 1 $\mathrm{ml}$ of ISC was given and followed by a 15 minutes window period. Formula used to calculate the iron requirement of the patient to fulfill the deficient as well as to replenish the Iron Stores were calculated as follows - [TDI (Total dose infusion) $=$ Wt. $(\mathrm{kg}) \times.(120 \mathrm{~g} / \mathrm{L}-$ Actual Haemoglobin $\mathrm{g} / \mathrm{L}) \times 0.24+500 \mathrm{mg}]$. Blood sample where taken before the start of the therapy and at 4 weeks interval to evaluate the level of $\mathrm{Hb}, \mathrm{MCV}$, serum ferritin, serum iron and TIBC values.

\section{Follow-up}

\section{Oral group}

Subjects were asked to bring the empty strips on every visit. Patients were asked on every visit about any side effect related to iron tablets intake, like heartburn, nausea, vomiting, gastric upset, diarrhea and constipation etc. and were recorded in the questionnaire along with complete antenatal checkup which was done routinely on regular intervals.

\section{Intravenous group}

Iron sucrose complex infusion was given. Side effect or allergy was asked after every cycle of infusion along with side effect related to iron therapy; were recorded in the questionnaire form. The cases were followed till delivery and the outcome was noted.

\section{Statistical analysis}

After accumulation of the data the statistical analysis was done using SPSS (Statistical Package for Social Sciences) Version 15.0. The values were represented in number (\%) and Mean \pm SD. Independent sample-t test and, Chi square test were used for statistical analysis. $\mathrm{P}<0.05$ was considered significant.

\section{RESULTS}

A total of 160 subjects were enrolled in the study. Majority of subjects $(n=106 ; 66.3 \%)$ were in age group 21-30 years followed by $31-40$ years $(n=42 ; 26.3 \%)$ and then $<20$ years $(n=12 ; 7.5 \%)$.

An equal number of subjects were Para 0 and Para 1 (37.5\%) followed by Para $2(18.8 \%)$ and Para $3(6.3 \%)$. Out of total number of patients registered, $77(48.1 \%)$ subjects were from rural and $83(51.9 \%)$ subjects were from urban area.

In Group A, majority of subjects $(55 \%)$ was from rural area while in Group B majority of subjects (58.8\%) were from urban area. Almost half the subjects (48.8\%) were graduate or above. Only $8.1 \%$ subjects were illiterate. Almost half the subjects $(49.4 \%)$ had a monthly family income between Rs 5001-10000.

Majority of subjects in both the groups were enrolled at gestational age 16-20 weeks. In oral group, 9 (11.25\%) subjects were enrolled at gestational age 26-30 weeks while in I.V. group $10(12.5 \%)$ subjects were enrolled at this gestational age. Only $12.5 \%$ subjects reported to be performing heavy physical activity while $21.9 \%$ were performing mild physical activity.

None of the subjects was having a sedentary lifestyle. Non-vegetarians comprised less than a quarter of subjects in both the groups. In group A maximum number of subjects had a BMI between 18-25 while in Group B maximum number of subjects had a BMI between 25-30 $\mathrm{kg} / \mathrm{m}^{2}$. Thus, demographically and anthropometrically, both the groups were matched.

At baseline, majority of subjects in both the groups had hemoglobin levels between 9.1-10 gm\% followed by those with hemoglobin levels between 8.1-9 gm\%. There were $6.25 \%$ subjects in Group I and $11.25 \%$ subjects in Group II with hemoglobin levels below $8 \mathrm{gm} \%$ at baseline. On comparing the data statistically, no significant difference was seen between two groups (Table 1).

At baseline, no statistically significant difference in mean $\mathrm{MCV}$ of two groups was seen $(\mathrm{p}=0.281)$.

However, from follow up at 24 weeks and thereafter till the term the mean MCV of Group II was significantly higher as compared to that of Group I $(p<0.05)$. But at postpartum observation no significant difference between two groups was seen. At baseline the mean $\mathrm{S}$. 
Table 1: Comparison of baseline characteristics of the study population in two groups.

\begin{tabular}{|c|c|c|c|c|c|c|}
\hline \multirow{2}{*}{ Variable } & \multicolumn{2}{|c|}{ Oral $(n=80)$} & \multicolumn{2}{|c|}{ I.V. $(n=80)$} & \multicolumn{2}{|c|}{ Total } \\
\hline & No. & $\%$ & No. & $\%$ & No. & $\%$ \\
\hline \multicolumn{7}{|l|}{ Age-group } \\
\hline$\leq 20$ Years & 6 & 7.5 & 6 & 7.5 & 12 & 7.5 \\
\hline 21-30 Years & 54 & 67.5 & 52 & 67.5 & 106 & 66.3 \\
\hline $31-40$ Years & 20 & 25 & 22 & 25.0 & 42 & 26.3 \\
\hline \multicolumn{7}{|l|}{$\chi^{2}=0.133(\mathrm{df}=2) ; \mathrm{p}=0.936$} \\
\hline \multicolumn{7}{|l|}{ Parity } \\
\hline 0 & 31 & 38.8 & 29 & 36.3 & 60 & 37.5 \\
\hline 1 & 30 & 37.5 & 30 & 37.5 & 60 & 37.5 \\
\hline 2 & 15 & 18.8 & 15 & 18.8 & 30 & 18.8 \\
\hline 3 & 4 & 5.0 & 6 & 7.5 & 10 & 6.3 \\
\hline \multicolumn{7}{|l|}{$\chi^{2}=0.467(\mathrm{df}=3) ; \mathrm{p}=0.926$} \\
\hline \multicolumn{7}{|l|}{ Residence } \\
\hline Rural & 44 & 55.0 & 33 & 41.3 & 77 & 48.1 \\
\hline Urban & 36 & 45.0 & 47 & 58.8 & 83 & 51.9 \\
\hline \multicolumn{7}{|l|}{$\chi^{2}=3.029(\mathrm{df}=1) ; \mathrm{p}=0.082$} \\
\hline \multicolumn{7}{|l|}{ Educational Status } \\
\hline Illiterate & 2 & 2.5 & 11 & 13.75 & 13 & 8.1 \\
\hline Just literate & 8 & 10.0 & 9 & 11.25 & 17 & 10.6 \\
\hline High School/Intermediate & 24 & 30.0 & 28 & 35.0 & 52 & 32.5 \\
\hline Graduate & 33 & 41.25 & 25 & 31.25 & 58 & 36.3 \\
\hline Postgraduate and above & 13 & 16.25 & 7 & 8.75 & 20 & 12.5 \\
\hline \multicolumn{7}{|l|}{$\chi^{2}=9.501(\mathrm{df}=4) ; \mathrm{p}=0.050$} \\
\hline \multicolumn{7}{|l|}{ Occupation } \\
\hline Housewife & 67 & 83.75 & 66 & 82.5 & 133 & 83.1 \\
\hline Working & 13 & 16.25 & 14 & 17.5 & 27 & 16.9 \\
\hline \multicolumn{7}{|l|}{$\chi^{2}=0.045(\mathrm{df}=1) ; \mathrm{p}=0.833$} \\
\hline Monthly family income & & & & & & \\
\hline$\leq$ Rs 2000 & 1 & 1.25 & 2 & 2.5 & 3 & 1.9 \\
\hline $2001-5000$ & 28 & 35.0 & 29 & 36.25 & 57 & 35.6 \\
\hline $5001-10000$ & 41 & 51.25 & 38 & 47.5 & 79 & 49.4 \\
\hline $10001-20000$ & 10 & 12.5 & 11 & 13.75 & 21 & 13.1 \\
\hline$\chi^{2}=0.512(\mathrm{df}=3) ; \mathrm{p}=0.916$ & & & & & & \\
\hline Gestational age (weeks) & & & & & & \\
\hline $16-20$ weeks & 49 & 61.25 & 41 & 51.25 & 90 & 56.3 \\
\hline $21-25$ weeks & 22 & 27.5 & 29 & 36.25 & 51 & 31.9 \\
\hline 26-30 weeks & 9 & 11.25 & 10 & 12.5 & 19 & 11.9 \\
\hline$\chi^{2}=1.725(\mathrm{df}=2) ; \mathrm{p}=0.422$ & & & & & & \\
\hline Physical activity & & & & & & \\
\hline Mild & 23 & 28.75 & 12 & 15.0 & 35 & 21.9 \\
\hline Moderate & 49 & 61.25 & 56 & 70.0 & 105 & 65.6 \\
\hline Heavy & 8 & 10.0 & 12 & 15.0 & 20 & 12.5 \\
\hline$\chi^{2}=4.724(\mathrm{df}=2) ; \mathrm{p}=0.094$ & & & & & & \\
\hline Dietary habits & & & & & & \\
\hline Non-Vegetarian & 18 & 22.5 & 17 & 21.3 & 35 & 21.9 \\
\hline Vegetarian & 62 & 77.5 & 63 & 78.8 & 125 & 78.1 \\
\hline$\chi^{2}=0.037(\mathrm{df}=1) ; \mathrm{p}=0.848$ & & & & & & \\
\hline BMI category $\left(\mathrm{kg} / \mathrm{m}^{2}\right)$ & & & & & & \\
\hline$<18$ & 1 & 1.25 & 2 & 2.5 & 3 & 1.9 \\
\hline $18-25$ & 33 & 41.25 & 28 & 35 & 61 & 38.1 \\
\hline $25-30$ & 30 & 37.50 & 38 & 47.5 & 68 & 42.5 \\
\hline$>30$ & 16 & 20 & 12 & 15.0 & 28 & 17.5 \\
\hline$\chi^{2}=2.256(\mathrm{df}=3) ; \mathrm{p}=0.521$ & & & & & & \\
\hline Complications & & & & & & \\
\hline No H/o previous complications & 65 & 81.25 & 64 & 80.0 & 129 & 80.6 \\
\hline Low birth weight & 9 & 11.25 & 12 & 15 & 21 & 13.12 \\
\hline Previous LSCS & 6 & 7.5 & 4 & 5.0 & 10 & 6.3 \\
\hline H/o previous abortions & 16 & 20 & 19 & 23.75 & 35 & 21.87 \\
\hline$\chi^{2}=1.048(\mathrm{df}=3) ; \mathrm{p}=0.790$ & & & & & & \\
\hline Hemoglobin level category & & & & & & \\
\hline$\leq 8$ & 5 & 6.25 & 9 & 11.25 & 14 & 8.8 \\
\hline $8.1-9$ & 22 & 27.5 & 18 & 22.5 & 40 & 25.0 \\
\hline $9.1-10$ & 53 & 66.25 & 53 & 66.25 & 106 & 66.3 \\
\hline
\end{tabular}


Table 2: Comparison of MCV, serum ferritin and transferrin saturation values at baseline and follow up in two groups.

\begin{tabular}{|lllllll|}
\hline Weeks of gestation & $\begin{array}{l}\text { Oral }(\mathbf{n = 8 0}) \\
\text { Mean }\end{array}$ & SD & Mean & SD & Statistical Significance & p \\
\hline MCV values & & & & & & \\
\hline Baseline & 70.91 & 3.46 & 70.33 & 3.38 & 1.083 & 0.281 \\
\hline 24 wk & 72.14 & 3.14 & 73.19 & 3.02 & 2.141 & 0.034 \\
\hline 28 wk & 73.55 & 2.90 & 76.79 & 2.87 & 7.088 & $0.001^{*}$ \\
\hline 32 wk & 76.55 & 2.63 & 79.40 & 2.43 & 7.132 & $0.001^{*}$ \\
\hline At term (36 wk) & 79.54 & 1.47 & 81.67 & 2.24 & 7.123 & $0.001^{*}$ \\
\hline PP & 78.89 & 0.81 & 80.29 & 9.21 & 1.358 & 0.176 \\
\hline S. Ferritin & & & & & & \\
\hline Baseline & 17.66 & 5.81 & 15.82 & 5.39 & 2.070 & 0.040 \\
\hline First FU & $59.68^{*}$ & 18.02 & $111.18^{*}$ & 57.00 & 7.702 & $<0.001^{*}$ \\
\hline Second FU & $55.29^{*}$ & 16.56 & $66.69^{*}$ & 16.43 & 4.028 & $<0.001^{*}$ \\
\hline At term & $45.37^{*}$ & 13.93 & $54.89^{*}$ & 16.42 & 3.956 & $<0.001^{*}$ \\
\hline Transferrin saturation & & & & & & \\
\hline Baseline & 9.79 & 1.59 & 9.85 & 1.45 & 0.227 & 0.821 \\
\hline Follow-up & $10.33^{*}$ & 1.85 & 19.37 & $3.26^{*}$ & 21.568 & $<0.001^{*}$ \\
\hline At term & $18.60^{*}$ & 3.77 & 26.89 & $4.58^{*}$ & 12.516 & $<0.001^{*}$ \\
\hline p & & & & & & \\
\hline
\end{tabular}

*p value significant

Ferritin levels in Group II were significantly lower as compared to Group I ( $\mathrm{p}=0.040$ ) but from first follow up onwards the mean S. ferritin levels of Group II subjects were significantly higher as compared to that of Group I subjects $(p<0.001)$. At all the time intervals the difference from baseline in both the groups was significant statistically $(\mathrm{p}<0.001)$ (Table 2).
There was significant rise in haemoglobin levels in both the groups, but rise in IV treated group, was significantly higher than the orally treated group $(\mathrm{p}<0.001)$. It means that haemoglobin values at all times points after 4 weeks of therapy were higher in the intravenous treated group (Table 3).

Table 3: Comparison of rise in haemoglobin value in both groups from baseline till term.

\begin{tabular}{|c|c|c|c|c|c|c|c|c|c|c|}
\hline \multirow{3}{*}{$\begin{array}{l}\text { Haemoglobin level } \\
(\mathrm{gm} \%)\end{array}$} & \multicolumn{5}{|c|}{ Oral $(n=80)$} & \multicolumn{5}{|c|}{ I.V. $(n=80)$} \\
\hline & \multirow{2}{*}{ Before } & \multicolumn{4}{|c|}{ At term } & \multirow{2}{*}{ Before } & \multicolumn{4}{|c|}{ At term } \\
\hline & & 7-8.9 & $9-9.9$ & 10-11.9 & $>12$ & & $7-8.9$ & $9-9.9$ & 10-11.9 & $>12$ \\
\hline $7-8.9$ & 20 & 1 & 6 & 13 & 0 & 19 & 0 & 3 & 16 & 0 \\
\hline $9-9.9$ & 50 & 0 & 0 & 50 & 0 & 52 & 0 & 0 & 41 & 11 \\
\hline 10 and above & 10 & 0 & 0 & 10 & 0 & 9 & 0 & 0 & 3 & 6 \\
\hline $\begin{array}{l}\text { Statistical significance } \\
\text { of change in each group }\end{array}$ & \multicolumn{5}{|c|}{$Z=7.751 ; p<0.001^{*}$} & \multicolumn{5}{|c|}{$\mathrm{Z}=7.938 ; \mathrm{p}<0.001^{*}$} \\
\hline \multicolumn{11}{|c|}{ Group I vs Group II, Before treatment $=\mathrm{Z}=0.020 ; \mathrm{p}=0.984(\mathrm{NS})$, After treatment $=\mathrm{Z}=4.097 ; \mathrm{p}<0.001^{*}$} \\
\hline
\end{tabular}

Table 4: Iron nutrition indicators at baseline and at term of gestation.

\begin{tabular}{|c|c|c|c|c|c|c|c|c|}
\hline \multirow{3}{*}{$\begin{array}{l}\text { Time interval } \\
\text { Baseline }\end{array}$} & \multicolumn{4}{|l|}{ Oral } & \multicolumn{4}{|l|}{ I.V. } \\
\hline & \multicolumn{2}{|c|}{ S. Ferritin } & \multicolumn{2}{|l|}{ TS\% } & \multicolumn{2}{|c|}{ S. Ferritin } & \multicolumn{2}{|l|}{ TS\% } \\
\hline & 17.66 & 5.81 & 9.79 & 1.59 & 15.82 & 5.39 & 9.85 & 1.45 \\
\hline Term & 45.37 & 13.93 & 18.60 & 3.77 & 54.89 & 16.42 & 26.89 & 4.58 \\
\hline Difference & 27.71 & 13.07 & 8.80 & 2.62 & 39.07 & 12.26 & 17.05 & 3.47 \\
\hline $\begin{array}{l}\text { Significance of difference } \\
\text { (baseline versus term) }\end{array}$ & \multicolumn{2}{|c|}{$\mathrm{t}=18.968 ; \mathrm{p}<0.001$} & \multicolumn{2}{|c|}{$\mathrm{t}=30.089 ; \mathrm{p}<0.001$} & \multicolumn{2}{|c|}{$\mathrm{t}=28.50 ; \mathrm{p}<0.001$} & \multicolumn{2}{|c|}{$\mathrm{t}=43.891 ; \mathrm{p}<0.001$} \\
\hline
\end{tabular}


At baseline the transferrin saturation was matched between two groups but at both the intervals thereafter the mean TS\% in Group B was significantly higher as compared to that of Group A. In both the groups a significant increment in both the indicators i.e. serum ferritin and TS\% was seen $(\mathrm{p}<0.001)$ (Table 4).

Table 5: Comparison of side effects profile in both the groups.

\begin{tabular}{|lllllll|}
\hline Side effects & Oral $(\mathbf{n}=\mathbf{8 0})$ & & I.V. $(\mathbf{n = 8 0})$ & \multicolumn{2}{l|}{ Statistical significance } \\
\hline Nausea/vomiting & No. & $\mathbf{\%}$ & $\mathbf{N o .}$ & $\mathbf{\%}$ & $\boldsymbol{\chi}^{\mathbf{2}}$ & $\mathbf{p}$ \\
\hline Diarrhoea & 21 & 26.25 & 3 & 3.75 & 15.882 & $<0.001^{*}$ \\
\hline Anaphylaxis & 12 & 15.0 & 3 & 3.75 & 5.959 & $0.015^{*}$ \\
\hline Hypotension & 0 & 0 & 2 & 2.5 & 2.025 & 0.155 \\
\hline Headache & 0 & 0 & 4 & 5.00 & 4.103 & 0.043 \\
\hline Metallic taste & 7 & 8.75 & 7 & 8.75 & 0 & 1 \\
\hline Arthralgia & 7 & 8.75 & 14 & 17.75 & 2.791 & 0.095 \\
\hline Itching & 3 & 3.75 & 12 & 15.0 & 5.959 & $0.015^{*}$ \\
\hline Rashes & 2 & 2.5 & 17 & 21.3 & 13.438 & $<0.001^{*}$ \\
\hline Fever & 2 & 2.5 & 8 & 10.0 & 3.840 & 0.050 \\
\hline Thrombophlebitis & 2 & 2.5 & 8 & 10.0 & 3.840 & 0.050 \\
\hline Dyspepsia & 2 & 2.5 & 26 & 32.5 & 24.935 & $<0.001^{*}$ \\
\hline Abdominal cramps & 15 & 18.75 & 3 & 3.75 & 9.014 & $0.003^{*}$ \\
\hline Constipation & 9 & 11.25 & 2 & 2.5 & 4.783 & $0.029^{*}$ \\
\hline
\end{tabular}

*p value significant

Table 6: Comparison of neonatal outcome in both the groups.

\begin{tabular}{|c|c|c|c|c|c|c|}
\hline \multirow{2}{*}{ Variable } & \multicolumn{2}{|c|}{ Oral $(n=80)$} & \multicolumn{2}{|c|}{ I.V. $(n=80)$} & \multicolumn{2}{|c|}{ Statistical significance } \\
\hline & No. & $\%$ & No. & $\%$ & $\chi^{2}$ & $\mathbf{P}$ \\
\hline \multicolumn{7}{|l|}{ Baby weight } \\
\hline$<2.5 \mathrm{~kg}$ & 20 & 25.00 & 9 & 11.3 & \multirow{3}{*}{5.672} & \multirow{3}{*}{0.059} \\
\hline $2.5-3.0 \mathrm{~kg}$ & 43 & 53.75 & 55 & 68.8 & & \\
\hline$>3 \mathrm{~kg}$ & 17 & 21.25 & 16 & 20.0 & & \\
\hline Preterm & 12 & 66.7 & 5 & 6.25 & 3.225 & 0.073 \\
\hline IUGR & 8 & 10.0 & 4 & 5.0 & 1.441 & 0.230 \\
\hline Mean neonatal Haemoglobin at birth & \multicolumn{2}{|c|}{$16.88 \pm 1.96$} & \multicolumn{2}{|c|}{$18.09 \pm 0.96$} & \multicolumn{2}{|c|}{$\mathrm{p}<0.0001^{*}$} \\
\hline
\end{tabular}

Incidence of nausea/vomiting, diarrhoea, dyspepsia, abdominal cramps and constipation was significantly higher in oral Group while incidence of hypotension, arthralgia, itching, rashes, fever and thrombophlebitis was significantly higher in IV group (Table 5).

No statistically significant difference between two groups was seen for any of the neonatal outcomes except mean neonatal haemoglobin at birth which was found to be significantly higher in IV group as compared to oral group $(\mathrm{p}<0.001)($ Table 6$)$.

\section{DISCUSSION}

Present study is a prospective randomized controlled trial, in which we aimed to compare the efficacy and side effects of iron therapy. In present study both the groups were comparable in terms of parity, socio-demographic as well as anthropometric data. The rise in hemoglobin level was significantly faster in IV Group as compare to oral group $(<0.001)$ throughout pregnancy.

In agreement to present study, studies done by $\mathrm{Al}$ Momen et al, Ragip A et al, Singh K et al, Giannoulis C et al, Bandal et al and Dede A et al had also reported faster and better hemoglobin response of IV Iron, although study done by Bencaiova $\mathrm{G}$ et al, did not find better response in IV group in comparison to oral group. ${ }^{13-20}$

Faster and better hemoglobin response of IV iron might be due to high amount of iron or better availability of iron for hemopoietic cells. From first follow up onwards the mean serum ferritin levels of IV group was significantly higher as compared to oral group $(\mathrm{p}<0.001)$.

At all the time intervals, the difference from baseline in both the groups was significant statistically $(\mathrm{p}<0.001)$. 
This was similar with studies done by Al- Momen et al, Bayoumeu et al, Ragip et al, Bencaiova G et al and Singh $\mathrm{K}$ et al and Bhandal et al had also reported similar results. ${ }^{13-15,17,19,20}$ In follow up and at term the mean transferring saturation of IV group was significantly higher as compared to oral group $(\mathrm{p}<0.001)$. At all the time intervals, the difference from baseline in both the groups was statistically significant $(\mathrm{p}<0.001)$.

Study by Singh K et al had also reported similar results. ${ }^{15}$ Follow up at 24 weeks and thereafter till the term the mean MCV of IV group was significantly higher as compared to that of oral group $(p<0.05)$. This was comparable with the study of Momen A et al had also reported similar finding in their study. ${ }^{13}$

The side effects were comparable to the studies by other author as shown in the previous studies done by $\mathrm{Al}$ Momen et al, Bayaumen F et al, Ragip A et al, Bencaiova $\mathrm{G}$ et $\mathrm{al}$ and they had also reported very high incidence of constipation, nausea, vomiting, dyspepsia and other GI symptoms and non-compliance due to GI upset in the oral group as compared to the intravenous group. ${ }^{13,14,19,20}$

In the study by Oskiet al in new born with iron deficiency anemia is associated with poor performance in the Baylee Mental development Index. ${ }^{21}$ In another study done by Idjradinata $\mathrm{P}$ et al children born to mother with iron deficiency anemia shows poor mental and motor performance but it improve with Iron therapy in iron deficit infants at $12-18$ months of age. ${ }^{22}$ Similar findings are also enlightened from the present study.

\section{CONCLUSION}

The improvement in serum ferritin and haemoglobin levels was satisfactory in both intervention groups. Intravenous iron sucrose was quite efficient and faster acting than oral for treatment of moderate iron supplement to severe anaemia. But, to keep the risk of adverse effects within limits, parenteral iron injections must be administered in healthcare settings.

Funding: No funding sources

Conflict of interest: None declared

Ethical approval: The study was approved by the Institutional Ethics Committee

\section{REFERENCES}

1. Anaemia is on the rise in India says NFHS report. [Online]. 2008 Jul 17 [cited 2010 Oct 27]; Available at URL:http://www.expressindia.com/latestnews/Anaemia-is-on-the-rise-in-India-says-NFHSreport/336854

2. World Health Organization, Centers for Disease Control and Prevention. de Benoist B, McLean E, Egli I, Cogswell M, eds. Worldwide prevalence of anaemia 1993-2005. Geneva, World Health Organization, 2008.
3. Letsky EA. The hematological system. In clinical physiology in obstetric ( $2^{\text {nd }}$ ed.) Blackwell Science, Oxford publications; 1991:39-82.

4. Premonanda B, Som, Superna, Chakrabaety, Manoranjan P, et al. Prevalence of anemia and its determinants among non pregnant and pregnant women in India. Asia Pacific J Health. 2008;20:34759.

5. Looker AC, Dallman PR. Prevalence of Iron deficiency United States. JAMA. 1997;277(97):9736.

6. Scott DE. Anemia during pregnancy. Obstet Gynecol Ann. 1972;1:219.

7. Perry GS, Yip R, Zyrkowski C. Nutritional risk factors among low-income pregnant US women: the Centers for Disease Control and Prevention (CDC) Pregnancy Nutrition Surveillance System, 1979 through 1993. Semin Perinatol. 1995;19(3):211-21.

8. Schooll TO, Hediger ML, Fisher RL, Shearer JW. Anemia versus iron deficiency: increased risk of preterm delivery in a prospective study. Am J Clin Nutr. 1992;55:985-8.

9. Mukherji J, Ganguly RP, Saha SK, Ray SCH. Postpartum care: a neglected tragedy. J Obstet Gynecol India. 2002;52(4):40-3.

10. Indian Council of Medical Research Supplementation trial in pregnant women with $60 \mathrm{mg}$, $120 \mathrm{mg}$ and $180 \mathrm{mg}$ Iron with 500 of folic acid, New Delhi, ICMR. 1992:641.

11. Schultink W. Iron supplementation programmes: Compliance of target groups and frequency of tablet intake. Food Nutr Bull. 1996;17:22-6.

12. WHO fact sheet no. 276/Feb. 2004. WHO. The World Health Report: Redwing ristis, promoting healthy life, Geneva, 2002.

13. Al Momen AK, Al Meshari A, al Nuaim L, Saddique $\mathrm{A}$, Abotalib Z, Khashog $\mathrm{T}$ et al. Intervention iron sucrose complex in the treatment of iron deficiency anemia during pregnancy. Eurp J Obstet Gynecol. Reprod Biol. 1956;69:121-4.

14. Al RA, Unlubilgin E, Kandemir O, Yalvaes Cakir L, Haberal A. Intravenous versus oral Iron for treatment of Anemia in pregnancy, Randomized trial. Am J Obstet Gynecol. 2005;106(6):1335-40.

15. Singh K, Fong YF, Kuperan P. A comparison between intravenous iron Polymaltose complex and oral ferrous fumarate deficiency in the treatment of iron deficiency anemia in pregnancy. Eur $\mathbf{J}$ Haematol. 1998;60:119-124.

16. Millman N, Bergholt, Byg KE, Eri K. Iron standard Iron balance during pregnancy. A critical re appraisal of Iron supplements. Acta Obst Conti Acta Obstet Gynecol Scand. 1969;78:749-57.

17. Bhandal N, Russell R. Intravenous verses oral iron therapy for postpartum anemia British $\mathbf{J}$ Obstet Gynecol. 2006:1248-52.

18. Dede A, Uygur D, Yilmaz B. Intravenous iron sucrose complex verses ferrous sulphate for postpartum iron deficiency anemia. Int $\mathbf{J}$ Obstet Gynecol. 2005;90:238-9. 
19. Bayoumeu F, Subiran Buisset C, Baka NE, Legagneur H, Monnier-Barbarino P, Laxenaire MC et al. Iron therapy in iron deficiency anemia in pregnancy: intravenous versus oral route. Am J Obstet Gynecol. 2002;186(3):518-522.

20. Bencaiova G, von Mandach U, Zimmermann R. Iron prophylaxis in pregnancy: intravenous route versus oral route. Eur J Obstet Gynecol Reprod Biol. 2009;144(2):135-9.

21. Oski FA. Iron deficiency in infancy and childhood. $\mathrm{N}$ Engl J Med. 1993;329:190-3.
22. Idjradinata P, Pollitt, E. Reversal of developmental delays in iron-deficient anaemic infants treated with iron. Lancet. 1993;341:1-4.

Cite this article as: Khan NZ, Ahmad M, Dwivedi AD, Shukla M. A comparative study on efficacy and safety of intravenous iron sucrose and oral iron among anaemic pregnant females. Int J Reprod Contracept Obstet Gynecol 2017;6:4492-9. 